\title{
Polen:
}

\section{Guds legeplads Vibeke Sperling}

\section{EU får et mere besværligt og uforudsigeligt Polen efter det jordskælvsagtige højreskred ved dette efterårs valg}

Polen har ved sine seneste valg levet op til titlen på den britiske forfatter Norman Davies' klassiker om polsk historie: Gods playground. Davies ser Polen som landet, hvor de store ideologiske konflikter i Europa altid sættes på spidsen.

I nyere tid skete det, da "Guds legeplads" i 1980'erne gik i front i opgøret med kommunismen på kontinentet. Og nu er det sket med et voldsomt højreskred og noget nær udradering af venstrefløjen fra det polske parlament ved parlamentsvalget 25. september. Det var Venstrealliancen (SLD), efterfølgeren for Kommunistpartiet, der denne gang fik polakkernes vrede at føle. Det blev reduceret til 11 procent af stemmerne fra 41 procent ved valget i 2001. Partiet blev trods pæne resultater i økonomien og sikring af Polens EU-medlemskab straffet for fire års ret visionsløst styre, bortset fra i udenrigspolitikken, og en stribe korruptionsskandaler.

Vinderpartierne søgte at gøre det til et opgør med postkommunismen, men det mest afgørende for vælgerne var efter alt at dømme den fortsat høje arbejdsløshed på 18 procent, EU's højeste, samt systematisk svigt af venstrefløjens traditionelle mærkesager i socialpolitikken.

SLD har som regeringsparti ført en liberalistisk økonomisk politik, og det var det erklærede højrefløjsparti, Lov og Retfærdighed (PiS), der løb med de sociale temaer ved at love mere til alle trængte grupper i samfundet.

Politisk repræsenterer PiS en patriotisk og katolsk højrefløj. Dets koalitionspartner, Borgerplatformen (PO), der kom på andenpladsen ved parlamentsvalget, ser derimod religion som en privat og ikke politisk sag. PO vil liberalisere økonomi- 
en og skære kraftigt ned i statsapparatet. PiS derimod ønsker stram statslig styring af økonomien for "et solidarisk Polen", som en af dets slagkraftige valgparoler lød. Når det gælder forholdet til omverdenen, er de to partier også vidt forskellige.

Det er to vidt forskellige verdensanskuelser, der mødes.

I en valgkamp, som i realiteten har stået på i over et år, viste PiS og PO en effektiv fælles front imod postkommunisterne og for opgør med korruption. Men da afgørelsens time nærmede sig, og det stod klart, at venstrefløjen var kørt helt ud på sidesporet, blev det til frontal konfrontation omkring de to visioner for Polens fremtid. PiS fremstillede PO som "kyniske liberalister", der "kun tænker på de rige". Og PO advarede stadig kraftigere imod PiS' halvautoritære syn på statens rolle og hævngerrighed over for postkommunisterne. "Jeg vil ikke være med til at gøre Polen til en stor undersøgelses- og straffekommission”, sagde PO's præsidentkandidat, Donald Tusk.

PiS har planer om at nedsætte en række kommissioner og retsinstanser til at gennemføre det opgør med de tidligere kommunister, som Polen aldrig har gennemført. Selv om PiS' præsidentkandidat, Lech Kaczynski, var med i de rundbordssamtaler, som i 1989 førte til kompromis med kommunisterne, har han siden raset imod, at retsopgøret aldrig blev taget.
Polens første ikke-kommunistiske ministerpræsident, Tadeusz Mazowiecki, sagde ved sin tiltrædelse, at der nu skulle slås "en streg i sandet". Da jeg mødte ham på det årlige Økonomiske Forum i september, sagde han: "Kritikerne af vort kompromis med kommunisterne er historieløse. De nægter nu at tage i betragtning, at Polen gik i spidsen for opgøret med kommunismen i Europa. Det kunne ikke have været gennemført så fredeligt uden vilje til i vist omfang at slå en streg over fortidens forbrydelser".

\section{Venstrefløjens fald}

Men før jeg vender tilbage til Polens nye magthavere, skal baggrunden for venstrefløjens fald ses gennem den sidste kommunistiske ministerpræsident og partileder, Mieczyslaw Rakowskis, øjne: "Højrepopulismens succes ved parlamentsvalget er et tragisk tilbageslag for den fornyende og moderniserende kraft, som satte Polen i spidsen for opgøret med kommunismen i Europa”.

Han giver Venstrealliancen (SLD) hovedskylden for tilbageslaget - det parti, som Rakowski og afgående præsident, Aleksander Kwasniewski, sammen lagde grunden til "en januarnat i 1990, efter at vi havde nedlagt kommunistpartiet”. Men SLD blev aldrig det moderne socialdemokrati, som han og Kwasniewski drømte om.

"På få år mistede partiet interes- 
sen for debat om fremtidsvisioner og kaldte sig pragmatisk. Pragmatisme kan være ok, men katastrofal uden visioner. Partibosserne ville kun ind på det nye borgerskabs bonede gulve og var rædselsslagne for de angreb fra antikommunister, der prægede 1990'erne".

Men de hastigt skiftende centrumhøjre regeringers fallit bragte venstrefløjen til magten igen. Da SLD vandt valget i 2001 med over 40 procent, kunne det regere praktisk talt alene.

"Det stod med et nyt magtmonopol, blev selvsmagende og de nye ledere opførte sig, som om de først var født i 1989. Jeg og andre skrev stribevis af advarende artikler uden nogen effekt", siger Rakowski. Han har nu i mange år koncentreret sig om at redigere tidsskriftet $D z i s$ og rollen som skarp og begavet kritiker af Polens politiske elite.

SLD vendte ryggen til den vesteuropæiske socialdemokratiske bevægelse. "Det næste blev at støtte krigen i Irak. Partiet gjorde Polen mere proamerikansk end nogensinde tidligere i historien. Det førte bl.a. til dårlige relationer til Tyskland. De glemte Tysklands særlige indsats for vort medlemskab af EU. Og nu har det nationalpopulistiske parti, PiS, stjålet det sociale program fra venstrefløjen. Disse ideologiske højreekstremister fremstår nu i sociale spørgsmål som mere venstreorienterede end SLD, der glemte Polens fattige og arbejdsløse".
Den demokratiske venstrefløj er nu hjemløs. "Det dybt tragiske er, at mange desillusionerede så undlod at stemme ved parlamentsvalget, og mange stemte på PiS. De venstreorienterede, der nu vender ryggen til politik, forstår ikke, at det halvautoritære PiS kan bane vejen for dem, som er endnu værre ved næste valg. Polen er et meget konservativt og katolsk samfund, men det stærkeste fællestræk er utilfredshed".

Den store ændring i polsk politik "er, at det for første gang siden kommunismens fald er lykkedes højrefløjen effektivt at udnytte den folkelige utilfredshed. Det er et åbent spørgsmål, hvor galt det kan gå, hvis Lech Kaczynski vinder præsidentvalget". (I skrivende stund ventes på afgørende runde i præsidentvalget 23. oktober.)

"Jeg kender Kaczynski-brødrene (præsidentkandidaten Lech og tvillingebroderen Jaroslaw, formand for PiS) og deres iver efter at jagte alle deres fjender. De må dæmpe den revolutionære retorik, for befolkningen ønsker ikke nye dramatiske omvæltninger".

Og vil Polen nu se en sand jagt på tidligere kommunister, som PiS vil udrense fra statsapparatet?

"Ja, efter al sandsynlighed, men al den snak om den postkommunistiske fare er ren propaganda, som befolkningen ikke køber. En ny meningsmåling viser, at kun to procent af polakkerne finder opgør med postkommunisterne meget vigtigt 
nu. Det handler om en fjern fortid. Nutidens bekymringer er fx, at 40 procent af de nyuddannede unge går ud i arbejdsløshed".

\section{Det manglende retsopgør}

Den tidligere kommunist mener, at et retsopgør med fortidens forbrydere burde have fundet sted for længe siden. "Men et opgør baseret på reelle og ikke virtuelle anklager, som tendensen er til nu".

Polen er mere uforudsigeligt end de fleste andre europæiske lande, medgiver Rakowski, men siger: "Det er ikke kun Polen, der plages af visionsløse bogholderpolitikere, der interesser sig mest for deres egen popularitetskurve. De utilfredse vande, som det skaber, svømmer populister som Kazcynski-brødrene i som glade guldfisk".

Og det visionsløse politiske EUlandskab kan ikke løse sine problemer med befolkningernes sociale utilfredshed eller med integrationen af de nye tidligere kommunistiske lande. Det kan simpelthen ikke "løse sine problemer med historien", hvilket ifølge Rakowski bl.a. giver sig udtryk i en manglende sammenhængende politik over for Polens store nabo Rusland.

Mange polske demokrater nærer en vis forhåbning til, at Wojciech Olejniczak - den nye unge leder, som SLD udpegede i foråret i erkendelse af, at katastrofen nærmede sig - kan forny det erklærede socialde- mokratiske parti. Men Olejniczak synes også at begå den fejl at fralægge sig ansvaret for historien. Anklager for at partiets forløber, Kommunistpartiet, under undtagelsestilstanden i 1980'erne med vold forsøgte at udslette fagforbundet Solidaritet, har han ofte afvist med ordene: "Jeg var kun seks år dengang”.

Det plager fortsat Polen, at det aldrig gennemførte et retsopgør.

Mens Tjekkiet indførte hårde såkaldte lustrations-love (lustration, latinsk for udrensning), er der kun sket en meget begrænset "lustration" i Polen. Mens fx STASI-arkiverne i det tidligere DDR blev åbnet fra 1992, er den hemmelige polske tjeneste, SB's, arkiver kun delvist gjort tilgængelige. Det har givet rum for politisk udnyttelse af dem. Selv Solidaritets skaber, Lech Walesa, har været under anklage for agentvirksomhed for SB.

Stadig nye agentanklager er dukket op som led i valgkampen. Polens førende dagblad, Gazeta Wyborcza, har kaldt det "vildfaren lustration". I begyndelsen af året blev en liste med 160.000 navne på folk, som skal have samarbejdet med SB, offentliggjort på internettet, angiveligt for at fremtvinge åbning af arkiverne i Instituttet for National Erindring (IPN).

Ledende anti-kommunister gik i 1989 imod åbning af arkiverne af frygt for, at det ville ramme uskyldige. I perioden fra august $1989 \mathrm{og}$ frem til januar 1990 menes op mod 
60 procent af arkiverne om Solidaritets-ledere og præster enten destrueret eller forsvundet. I december 1998 etablerede parlamentet IPN til at overvåge arkiverne, og der blev givet begrænset adgang for forskere.

I dag fylder arkiverne 80 hyldekilometer i IPN's sennepsgule bygning i Warszawas centrum. Ifølge IPN arbejdede 80.000 informanter for sikkerhedspolitiet sent i 1980'erne. Mange anklagede tidligere dissidenter hævder, at det er løgne i arkiverne, der stempler dem som forrædere. Men IPN's direktør, Leon Kieres, har ofte hævdet, at de "viser den fulde sandhed".

Det er folk fra hele Polens postkommunistiske elite, både tidligere kommunister og tidligere systemkritikere, der er hængt ud, men ifølge det respekterede ugemagasin Polity$k a$ har misbrug af arkiverne især gavnet højrefløjen.

\section{Folkelig utilfredshed}

Når man spørger almindelige polakker om PiS' planer om udrensning af postkommunister og kollaboratører fra alle poster i det offentlige liv, svarer de fleste, at nu bør politikerne koncentrere sig om fremtiden.

Den 50-årige lærer, Maryja Swydowska, siger: "De skulle have jaget kommunisterne på porten for 15 år siden. Nu bør de koncentrere sig om at løse om nutidens problemer".

"Vores skoler, sundhedsvæsen og veje falder sammen". "Nu kan vi sige alt, men det er alligevel som under kommunismen, for ingen lytter til jævne folk". "Nogen bliver fede af EU-tilskud, men de fleste bønder lever stadig i dyb fattigdom". Den slags pessimistiske udtalelser er typiske i dagens Polen. I provinsen dominerer pessimisterne, mens unge $\mathrm{i}$ det boomende Warszawa fnyser ad dem. "Man kan ikke dele den evige polske pessimisme her i byen", siger min unge ven Adam, der skændes med bedsteforældrene, "der lige som under kommunismen altid mener, at det hele går ad helvede til”.

Den dybe folkelige utilfredshed ses som baggrund for højreskredet og for, at næsten 60 procent af vælgerne blev væk fra stemmeurnerne ved parlamentsvalget og kun knap halvdelen stemte ved præsidentvalgets første valgomgang. Det er udtryk for krise i det polske demokrati og mangel på en moderne politisk kultur blandt vælgerflertallet.

"Da vi kæmpede for demokrati dengang i 1980'erne, drømte jeg ikke om, at mine medborgere ikke ville bruge det", sagde Walesa.

Politikerleden deler polakker med mange i EU, men som så mange andre fænomener er den særlig markant i Polen, hvor over 90 procent i en meningsmåling har erklæret, at de "ingen tillid har til politikerne".

Det er den gængse opfattelse, at en plads i sejmen (parlamentets underhus) kun bruges som billet til at 
stjæle. Kandidater til både sejmen, senatet (overhuset) og præsidentposten har snublet over hinandens ben med forsikringer om, at de er ærlige politikere, der vil rydde op. Kampen mellem vinderne, $\mathrm{PiS}$ og PO, stod om at vise, at de hver især var bedst til at sikre befolkningen dens retmæssige andel af værdierne.

PiS havde særligt effektive reklamespots på tv, især et om konsekvenserne af PO's forslag om lav, flad skat på 15 procent for både enkeltpersoner og virksomheder. Et fyldt køleskab blev vist og en stemme spurgte, hvad der vil ske med det med et skattesystem "til gavn for de rigeste". Og pist, alt forsvandt fra køleskabet. Fra et børneværelse fyldt med legetøj, forsvandt herlighederne lige så hurtigt. Og lyset gik ud, da det angiveligt bliver meget dyrere.

PO-ledere svarede igen med at stå frem sammen med tøjdyret Sylvester, som PiS lod forsvinde fra børneværelset, samt en gigantisk elpære. "Mere vil være der med flad skat", forsikrede PO.

\section{Økonomien}

Marek Belkas afgåede regering efterlader sig en problemfyldt, men i mange sektorer boomende økonomi, som de fleste polakker tilskriver EU-medlemskabet og ikke Venstrealliancen. Den takkes således ikke for sidste års økonomiske vækst på 5,4 procent, den højeste i syv år. Heller ikke for, at Polen er ved at genvinde sit ry som et af det mest attraktive steder at investere i Centraleuropa. Udenlandske investeringer ventes i år at overgå rekordåret 2000, hvor de var på 10,5 mia. dollar. Det tilskrives ikke mindst, at Belka-regeringen har brugt megen energi på at rydde op efter korruptionsskandaler under forgængeren Leszek Miller og gøre det økonomiske system mere åbent og gennemskueligt.

Belka har afleveret en færdig udviklingsplan for perioden 2007-2013 til sine efterfølgere, en plan for anvendelse af 137 mia. euro, hvoraf de 80 mia. kommer fra EU.

Polsk økonomi er regionens suverænt største og står for næsten halvdelen af BNP $i$ alle de ti nye EU-lande og til at modtage omkring halvdelen af EU-midlerne til de nye medlemslande, herunder hovedparten af midlerne til de fattigste regioner, hvoraf de fleste er at finde i Polen. Regioner i bundløs fattigdom skuler bittert til boomet i Warszawa og andre storbyer. Blandt en af de uheldige topplaceringer for Polen i EU er "den største forskel mellem de rigeste og fattigste", påpeger Mariusz Tys, international koordinator for byggeforbundet Budowlani.

Vinderalliancen er uenig om, hvornår Polen bør indføre euroen. Borgerplatformens økonomiske ekspert, tidligere nationalbankdirektør Hanna Gronkiewicz-Waltz siger: "Vi må gøre alt for at indføre euroen senest i 2009. Det vil formindske alle risici for økonomien”. En af Lov og 
Retfærdigheds økonomer, Cezary

Mech, siger:

"Polen vil ikke have fordel af euroen i nær fremtid. Vi har ikke brug for Den Europæiske Centralbank til at føre vores finanspolitik".

Blandt de positive udviklingstendenser, som frygtes sat over styr, er en lav inflation på halvanden procent og relativ balance i budgettet med et underskud kun lidt over EU's krav for indførelse af euroen.

\section{Det sociale tomrum}

Men fire år stort set uden andre visioner for regeringen end at blive ved magten skabte et "socialt tomrum åbent for hvad som helst. Folk uden store drømme er lige så farlige som dem med for mange", skrev ugemagasinet Polytika.

Bladet fremhæver det unægtelig meget glædelige, at flertallet af de vælgere, som stemte, ikke fyldte tomrummet med det ekstremistiske højrekatolske parti, Polske Familiers Liga og partiet Samoobrona (Selvforsvar), der svinger imellem højreog venstreekstremisme. Hvis ligaens formand, Roman Giertych, "ikke var sådan en operettefigur kunne polakkerne også have valgt ham".

Men de to partier fik dog omkring en femtedel af stemmerne ved parlamentsvalget, stemmer som især Lov og Retfærdighed appellerer til. Og Samoobronas formand, Andrzej Lepper, fik over 15 procent ved første valgrunde til præsidentposten.
Det var forbavsende meget efter en valgkamp, hvor medierne koncentrerede sig om Tusk og Kaczynski.

Det tjener PiS til ære, at det kategorisk afviste regeringssamarbejde med ekstremisterne, hvis det ikke lige var fordi det flirter med den ekstremistiske svinehund. Blandt brødrene Kaczynski yndlingsangrebsmål er bøsser og lesbiske. Lech blev verdensberømt, da han som borgmester i Warszawa i juni forbød en bøsseparade i byen med den begrundelse, at den både ville genere den offentlige moral og trafikken. Men ugen efter tillod han en "march for normalitet", som det aggressive ungdomsforbund under Ligaen for Polske Familier arrangerede imod "truslen imod de polske familier".

Kommentatoren Adam Krezeminski siger: "Kaczynski-brødrenes statsopfattelse er yderst farlig, fordi den er konfrontatorisk. Den bygger på fjendebilleder, udadtil især om Tyskland og Rusland og indadtil om kommunister og bøsser. De er ikke i det 21. århundrede, hvor national politik handler om alliancer og kompromiser. Men EU vil holde dem i ørerne".

De enæggede tvillingebrødre har været altdominerende i valgkampene, hvor Kaczynski-fænomenet fyldte lige så meget som politik. Tvillingerne har altid været uadskillelige og kæmpede sammen i den antikommunistiske oppositionen fra 1970'erne. De var begge nære samarbejdspartnere for grundlæggeren 
af fagforbundet Solidaritet i 1980 , Lech Walesa.

Noget at det eneste, som PO og PiS reelt har tilfælles er, at de begge er udgået af Solidaritet. Tidligere koalitioner af partier udgået af Solidaritet har haft meget ringe held med sig.

I valgkampens start lagde Kaczynski'erne ikke skjul på, at de gik efter hver sin af landets højeste poster, men Jaroslaw trak sig efter parlamentsvalget som ellers selvskreven til ministerpræsidentposten for at fremme Lechs chancer ved præsidentvalget. De erkendte, at flertallet af vælgerne ikke ønskede en præsident og ministerpræsident, som de ikke kan kende forskel på.

Tvillingerne tordner imod kriminalitet under enhver form og ønsker dødsstraf genindført. Under et interview, som jeg havde med ham i juni for dagbladet Politiken, sagde Lech til påpegningen af, at dødsstraf ikke kan forenes med Polens EU-medlemskab: "Jeg kræver kun dødsstraf for mord, og det er et rent polsk anliggende, som EU ikke skal blande sig i. Jeg er sikker på, at dødsstraf vender tilbage i mange EU-lande for at redde vores civilisation imod den stadig mere venlige behandling af kriminelle, der ofte behandles bedre end lovlydige". I valgkampens slutspurt gik Lech stille med kravet om dødsstraf, da det for mange også i hans eget parti er uforeneligt med deres moral. Men hyppig brug af livsvarigt fængsel "uden mulighed for appel" skal indføres, siger hans talsmand, Przemyslaw Gosiewski. Og der skal indføres "hård og øjeblikkelig afstraffelse af asocial adfærd som forstyrrelse af lov og orden, nattefred, moral mv.".

Selv om Donald Tusk og hans parti har vendt sig imod Kaczynski'ernes hævnlyst, ventes Borgerplatformen at give Lov og Retfærdighed, Lov og Orden, som mange kalder partiet, dets eftertragtede slikkepinde: indenrigsministeriet, sikkerhedstjenesten og justitsvæsenet. Dermed håber Tusks parti på mere rum for dets liberale økonomiske program.

Pawel Smolenski, politisk reporter ved Gazeta Wyborzca, siger: "Faren er, at de to brødre altid vil være vågne. Mens den ene sover, våger den anden. De vil overvåge os døgnet rundt. Men EU-medlemskabet er et anker, som de ikke kan trække op. Så bare rolig. De kan ikke rulle det demokrati tilbage, som har taget sikkert land i Polen". Men Polen kan blive en langt mere besværlig og uforudsigelig EU-partner.

\section{Besværlig partner}

Kaczynski-brødrene er udtalt anti-tyske og anti-russiske. De har desuden et parti med mange EU-skeptikere. Donald Tusk står for større forståelse med de store naboer, men er enig med Kaczynski'erne i kravet om, at EU lytter mere til de nye, tidligere kommunistiske medlemslande og deres erfaring med russerne. 
“Ændringerne i forhold til den nuværende politik vil blive tydelige. Indtil nu har Polens politik over for Rusland været fuld af smil og imødekommenhed", sagde Tusk under valgkampen. Han mener, at en "for eftergivende" polsk politik over for Rusland har medført, at Moskva blot har søgt at afpresse Polen ved enhver lejlighed. Der vil også blive tale om "en langt mere konsekvent støtte til Ukraine", lover Tusk. Der skal en del til for at overgå den konsekvente støtte, som Kwasniewski viste den ukrainske revolution til stor bitterhed for Moskva.

Men begge vinderpartier mener, at Kwasnievski "optrådte som forræder”, da han i maj deltog i 60-års festlighederne for Anden Verdenskrigs afslutning i Moskva, uden at Rusland havde efterkommet kravet om at sige undskyld for sovjetiske forbrydelser imod Polen, herunder mordet på omkring 15.000 polske officerer og intellektuelle i Katynskovene i Hviderusland under Anden Verdenskrig.

Der bliver ifølge Tusk tale om en politik over for Rusland "baseret på fasthed og historisk sandhed".

De nye polske magthavere lover også langt større pres på Hviderusland for demokratisering. Heri kan de nok blive mere enige med EU, end når det gælder Ruslands-politikken.

PO ønsker gode relationer til Tyskland, men er enige med PiS i, at tyskernes alliance med Ruslands præsident Putin under tidligere forbundskansler Gerhard Schröder er "forkastelig". Den tidligere venstreregering har med held, men også til stor frustration for mange i EU vist, at Polen ikke accepterer et EU med dominans for de store gamle medlemmer. Vinderalliancen anklager ikke blot Venstrealliancen for at have bøjet nakken for Polens historiske fjender, Rusland og Tyskland, men også for at have gjort det over for USA.

"Venstrealliancen har været overivrig for at vise proamerikansk sindelag. Vi har altid været pro-amerikanske, så vi har intet at skulle bevise, men vil markant ændre forholdet til USA. Vi vil styrke de transatlantiske bånd, men det er slut med betingelsesløs støtte til USA”, siger PO's internationale talsmand, Bronislaw Komorowski.

$\mathrm{Nu}$ skal stilles krav til gengæld for støtte til USA. Ifølge Komorowski vil de vigtigste krav blive mere støtte til udvikling af Polens væbnede styrker samt at Polen tages direkte med på råd om USA's politik over for dets naboer, primært Rusland. Amerikanerne skal også gå i dialog med Polen om fremtidige militæraktioner, der kan involvere polske soldater.

Det er i skrivende stund ikke afgjort, om Donald Tusk eller Lech Kaczynski bliver Polens næste præsident. Med føringen ved parlamentsvalget sikrede PiS sig under alle omstændigheder regeringslederposten og dermed størst indflydelse på in- 
denrigspolitikken. Præsidenten har derimod størst magt over udenrigspolitikken. (Lech Kaczynski blev valgt til polsk præsident den 23.10.05 med $54 \%$ af stemmerne, red.) Under alle omstændigheder kan ventes et mere selvhæudende Polen på den internationale scene.

Både PiS og PO udmærker sig ved stor mangel på internationale erfaringer i modsætning til den afgåede regering.

\section{Forskellige verdensanskuelser}

Ligegyldigt hvem præsidenten bliver, går regeringskoalitionen med to vidt forskellige verdensanskuelser et konfliktfyldt samliv i møde. Der gisnes i Warszawa om regeringen holder måneder, et år eller halvandet. De færreste uden for koalitionens egen kreds forventer, at den nye regering holder valgperioden ud.

Hvis vinderalliancen gennemfører løfter om at skabe et mere gennemskueligt og effektivt styre, kan det kun bifaldes. "Men som med WAS (en koalition af partier udgået af Solidaritet), der faldt i 2001, vil den nye regering sikkert bruge mere tid på interne slagsmål end på at gennemføre den lovede totale fornyelse af Polen", lyder en kommentar i Polytika.
Kaczynski-brødrenes nye afgørende indflydelse på Polen er formentlig et fænomen, der er kommet for at blive. Hverken når det gælder udrensning eller økonomisk politik, kan PO vente den store kompromisvilje fra brødrene, hvis varemærke er stædighed. Og de har opbakning fra hovedparten af de polakker, som ulejliger sig med at stemme, til deres løfter om mere statslig støtte til såvel middel- som underklassen.

Højreskredet viser paradoksalt nok, at de folkelige reflekser fra kommunismen ændres langsomt. Paradokset er, at Polens mest hårdnakkede anti-kommunistiske krigere, kan takke de instinkter i polakkerne, der stammer fra kommunismen, for deres magt. De instinkter appellerer brødrene Kaczynski til ved at love befolkningen en stat, der sørger for alle deres materielle behov.

Meget er usikkert i dagens Polen, men det forekommer givet, at guds legeplads bliver en del mindre forudsigelig end det Polen, som kom med i EU i 2004.

Vibeke Sperling er journalist på dagbladet Politiken. 